\title{
PENGARUH PEMBERIAN SPIRULINA PERORAL YANG DIBERI CCL 4 TERHADAP KADAR UREUM DAN KREATININ DARAH TIKUS PUTIH
}

\author{
1| Swandito Wicaksono \\ Email Korespondensi : swandito.dr@gmail.com \\ Departemen Fisiologi, Fakultas Kedokteran dan Ilmu Kesehatan, \\ Universitas Bengkulu, Indonesia
}

\begin{abstract}
Free radical is Carbon Tetra Chloride, which is organic toxic solution through liver, heart, and kidneys. Spirulina is green-blue algae which photosynthetic microalgae, spiral-shape, multicelullar and chemic-riched and able to correct body's damage by free radicals, for instance Beta Carotene, amino acids, Gamma Linolenic Acid (GLA). The aims of this research is to discover whether Spirulina can correct kidneys function from $\mathrm{CCl}_{4}$-induction on white rats (Rattus norvegicus) with weight \pm 300 gram. Decreasing kidneys fungtion was evaluated by increasing blood ureum and creatinine levels. ANOVA analysis performed that $\mathrm{CCl}_{4}$ effect blood ureum and creatinin $(p<0,05)$. Spirulina at dose 3,471 ml/300gr body weight was the most effective through correction kidneys function.

Abstrak

Radikal bebas Carbon Tetra Chloride merupakan pelarut organik yang bersifat toksik terhadap hati, jantung, dan ginjal. Spirulina adalah alga hijau-biru yang merupakan mikroalga fotosintetik, berbentuk spiral, multiseluler dan kaya senyawa kimia yang dapat memperbaiki berbagai kerusakan di dalam tubuh yang disebabkan karena radikal bebas, seperti Beta Carotene, Asam Amino, Gamma Linolenic Acid (GLA). Penelitian ini bertujuan untuk mengetahui efek dari Spirulina yang dapat memperbaiki kerusakan fungsi ginjal akibat induksi $\mathrm{CCl}_{4}$ pada tikus putih dilihat dari kadar ureum dan kreatinin darah. Penurunan fungsi ginjal terjadi pada hari pertama setelah aklimatisasi. Penurunan fungsi ginjal dapat dilihat dari kenaikan kadar ureum dan kreatinin darah. Hasil uji ANOVA pemberian $\mathrm{CCl}_{4}$ berpengaruh terhadap kenaikan ureum dan kreatinin darah $(\mathrm{p}<0,05)$. Spirulina 3,471 ml /300grBB merupakan dosis paling efektif dalam memperbaiki fungsi ginjal.
\end{abstract}

Kata Kunci: Radikal Bebas; Carbon Tetra Chloride $\left(\mathrm{CCl}_{4}\right)$; Ureum; Kreatinin; Spirulina

\section{PENDAHULUAN}

Radikal bebas adalah molekul yang sangat reaktif, karena memiliki elektron yang tidak berpasangan dalam orbital luarnya, sehingga dapat bereaksi dengan molekul sel tubuh dengan cara mengikat elektron dari molekul sel tersebut(1). Salah satu contoh radikal bebas adalah $\mathrm{CCl}_{4}$ (Carbon Tetra Chloride) yang banyak ditemukan pada cat, tinta, tiner, bahan perekat, kosmetik, dan lain-lain. $\mathrm{CCl}_{4}$ masuk ke dalam tubuh melalui jalur peroral, inhalasi, dan dermis(2). $\mathrm{CCl}_{4}$ yang masuk ke dalam tubuh manusia dapat menimbulkan berbagai macam efek, diantaranya mual, muntah, gagal ginjal akut, gagal ginjal kronik, gangguan hati, dan kerusakan sistem saraf pusat(3).

Gangguan pada hati dapat terjadi setelah 1-2 hari terpapar $\mathrm{CCl}_{4}$, sedangkan gangguan pada ginjal terjadi setelah 7-10 hari terpapar $\mathrm{CCl}_{4}(4) . \mathrm{CCl}_{4}$ menginduksi terjadinya peroksidasi lipid yang dipercaya menjadi penyebab utama kerusakan 
membran ginjal yang mengawali terjadinya keadaan patologis ginjal. Gagal ginjal akut karena paparan $\mathrm{CCl}_{4}$ dapat kembali normal dalam 6 bulan setelah paparan(5).

Gagal ginjal akut yang disebabkan karena $\mathrm{CCl}_{4}$ dapat dideteksi melalui pemeriksaan laboratorium ureum dan kreatinin darah untuk mengevaluasi fungsi ginjal(5). Penentuan kadar ureum bertujuan untuk mengukur jumlah urea, suatu produk buangan dari metabolisme protein di dalam darah. Urea dikeluarkan dari aliran darah melalui ginjal, suatu uji yang menentukan jumlah urea yang ada dalam darah dapat digunakan untuk menguji fungsi ginjal. Kreatinin diekskresi dalam urine melalui proses filtrasi dalam glomerulus. Meskipun sejumlah kecil diekskresi, uji kreatinin merupakan pemeriksaan yang dapat dipercaya untuk memperkirakan laju filtrasi glomerulus dalam klinik (6).

Penelitian yang dilakukan Henrikson (2000), menyebutkan bahwa kerusakan ginjal yang bersifat reversibel, seperti infeksi ginjal, sumbatan batu ginjal, penurunan fungsi ginjal dapat diperbaiki dengan menggunakan Spirulina(7). Spirulina adalah alga hijau-biru yang merupakan mikroalga fotosintetik, berbentuk spiral, multiseluler(8). Spirulina banyak mengandung berbagai jenis senyawa kimia, antara lain, vitamin, mineral, fikosianin, asam lemak esensial, asam lemak non esensial, asam amino esensial, asam amino non esensial, enzim-enzim, Beta Carotene, Gamma Linolenic Acid (GLA), dan nutrisi-nutrisi penting seperti Sulfopids, dan SOD(8). Beta Carotene yang terdapat di dalam Spirulina merupakan satu dari substansi yang sangat efektif untuk menonaktifkan molekul-molekul dasar yang telah menghancurkan sel-sel (radikal bebas). Beta Carotene merupakan antioksidan yang kuat Antioksidan mampu bergabung dengan molekul-molekul radikal tersebut dan mengurangi kerugian dari molekul-molekul tersebut(9).

Dengan dasar kandungan senyawa kimia yang terdapat dalam Spirulina yang dipercaya dapat memperbaiki penurunan fungsi ginjal, maka perlu dilakukan penelitian mengenai manfaat dan khasiat Spirulina terhadap penurunan fungsi ginjal ditinjau dari kadar ureum dan kreatinin darah. Apabila terbukti Spirulina dapat memperbaiki penurunan fungsi ginjal, diharapkan Spirulina dapat dijadikan obat alternatif dalam memperbaiki penurunan fungsi ginjal. Efek-efek $\mathrm{CCl}_{4}$ yang dapat merugikan kesehatan juga dapat dibuktikan dalam penelitian ini, terutama pengaruh $\mathrm{CCl}_{4}$ dalam mengakibatkan penurunan fungsi ginjal ditinjau dari kadar ureum dan kreatinin darah. Dalam penelitian ini digunakkan $\mathrm{CCl}_{4}$ sebagai penginduksi kerusakan ginjal tikus putih. Penelitian ini bertujuan untuk mengetahui efek $\mathrm{CCl}_{4}$, mengetahui pengaruh Spirulina dalam memperbaiki fungsi ginjal ditinjau dari kadar ureum dan kreatinin darah tikus putih yang diinduksi $\mathrm{CCl}_{4}$ peroral dan mengetahui dosis Spirulina yang paling efektif dalam menaikkan kadar ureum dan kreatinin tikus putih yang sebelumnya diinduksi $\mathrm{CCl}_{4}$ peroral.

\section{METODOLOGI PENELITIAN}


Penelitian ini menggunakan metode eksperimental menggunakan 24 tikus putih (Rattus Norvegicus) jantan, dengan berat badan rata-rata \pm 300 gram, yang dibagi menjadi 4 kelompok. Perhitungan jumlah sampel menggunakan rumus Federer, didapatkan hasil setiap kelompok terdiri dari 6 ekor tikus putih yang dipilih secara acak. Penelitian ini dilakukan selama 1 bulan. Sebelum diberi perlakuan, dilakukan aklimatisasi hewan coba selama 1 minggu. Pengukuran kadar ureum dan kreatinin darah dilakukan dengan cara mengambil darah melalui pembuluh darah ekor tikus 3 minggu setelah pemberian Spirulina cair peroral. Analisis data dengan uji ANOVA dilanjutkan dengan Uji Post Hoc, selanjutnya dilakukan Uji Homogeneous

Tabel 1. Pembagian kelompok dan perlakuan hewan coba

\begin{tabular}{lll}
\hline Kelompok & $\begin{array}{l}\text { Dosis CCl } \\
(\mathbf{m l / 3 0 0 g r B B})\end{array}$ & $\begin{array}{l}\text { Dosis Spirulina } \\
(\mathbf{m l} / \mathbf{3 0 0 g r B B})\end{array}$ \\
\hline Kontrol & - & - \\
\hline Perlakuan 1 (P1) & 0,81 & 1,735 \\
\hline Perlakuan 2 (P2) & 0,81 & 3,471 \\
\hline Perlakuan 3 (P3) & 0,81 & 6,942
\end{tabular}

\section{HASIL DAN PEMBAHASAN}

Tabel 2. Rerata hasil pengukuran kadar ureum dan kreatinin darah tikus putih 1 hari setelah diberi $\mathrm{CCl}_{4}$ peroral

\begin{tabular}{lll}
\hline Kelompok & $\begin{array}{l}\text { Kadar Ureum } \\
\mathbf{( m g / d \mathbf { l } )}\end{array}$ & $\begin{array}{l}\text { Kadar Kreatinin } \\
\mathbf{( m g / d l )}\end{array}$ \\
\hline Kontrol & 38,8 & 0,7 \\
\hline Perlakuan 1 (P1) & $70,5^{*}$ & $2,85^{*}$ \\
\hline Perlakuan 2 (P2) & $67,2^{*}$ & $3,05^{*}$ \\
\hline Perlakuan 3 (P3) & $63,2^{*}$ & $2,4^{*}$
\end{tabular}

Keterangan: ${ }^{*} \mathrm{p}<0.05$, membandingkan kelompok kontrol dengan kelompok perlakuan 1,2 , dan 3

Hasil pengukuran kadar ureum dan kreatinin darah tikus putih setelah pemberian $\mathrm{CCl}_{4}$ peroral $0,81 \mathrm{ml} / 300 \mathrm{grBB}$ tikus putih menunjukkan adanya 
peningkatan kadar ureum dan kreatinin darah pada kelompok perlakuan 1, 2, dan 3 dibandingkan dengan kelompok kontrol.

Hasil yang diperoleh menunjukkan bahwa $\mathrm{CCl}_{4}$ bersifat toksik terhadap ginjal, yang ditandai dengan kenaikan kadar ureum dan kreatinin darah, hasil ini sesuai dengan pernyataan Damansjah (1995) yang menyatakan bahwa $\mathrm{CCl}_{4}$ merupakan pelarut organik yang bersifat toksik terhadap hati, jantung, dan ginjal.

Karbon tetraklorida $\left(\mathrm{CCl}_{4}\right)$ merupakan xenobiotik yang lazim digunakan untuk menginduksi peroksidasi lipid dan keracunan. Dalam retikulum endoplasma retikulum hati $\mathrm{CCl}_{4}$ dimetabolisme oleh sitokrom P450 2E1 (CYP2E1) menjadi radikal bebas triklorometil $\left(\mathrm{CCl}_{3}\right) . \mathrm{CCl}_{3}$ dengan oksigen akan membentuk radikal triklorometilperoxi $\left(\mathrm{CCl}_{3} \mathrm{O}_{2}^{-}\right)$yang dapat menyerang lipid membran retikulum endoplasma dengan kecepatan melebihi $\mathrm{CCl}_{3}$, yang kemudian menyebabkan peroksidasi lipid dan akhirnya menyebabkan kematian sel(10).

Asam lemak penyusun membran sel, terutama asam lemak rantai Panjang tak jenuh (PUFA / Poly unsaturated fatty acid) sangat rentan terhadap radikal bebas. Jumlah PUFA dalam fosfolipid membran retikulum endoplasma akan berkurang sebanding dengan jumlah $\mathrm{CCl}_{4}$ yang diinduksikan. Pemberian $\mathrm{CCl}_{4}$ dalam dosis tinggi dapat merusak retikulum endoplasma, mengakumulasi lipid, mengurangi sintesis protein, mengacaukan proses oksidasi, menurunkan berat badan, menyebabkan kerusakan pada hati dan ginjal(10).

Tabel 3. Rerata hasil pengukuran kadar ureum dan kreatinin darah tikus putih setelah pemberian Spirulina cair selama 3 minggu dengan dosis berbeda

\begin{tabular}{lll}
\hline Kelompok & $\begin{array}{l}\text { Kadar Ureum } \\
(\mathbf{m g} / \mathbf{d l})\end{array}$ & $\begin{array}{l}\text { Kadar Kreatinin } \\
(\mathbf{m g} / \mathbf{d l})\end{array}$ \\
\hline Perlakuan 1 (P1) & 42,5 & 0,88 \\
\hline Perlakuan 2 (P2) & 35,2 & 0,82 \\
\hline Perlakuan 3 (P3) & 45 & 0,88
\end{tabular}

Hasil pengukuran kadar ureum dan kreatinin darah tikus putih setelah pemberian Spirulina cair peroral dengan dosis berbeda setiap kelompok perlakuan selama 3 minggu (kelompok perlakuan 1, 2, dan 3), didapatkan adanya penurunan kadar ureum dan kreatinin darah dibandingkan dengan sebelum pemberian Spirulina cair peroral. Penurunan kadar ureum dan kreatinin darah tikus putih paling tinggi dapat terlihat pada kelompok perlakuan 2, diberi Spirulina cair peroral selama 3 
minggu dengan dosis 3,471 ml/300grBB tikus putih. Tetapi secara statistik, tidak didapatkan dosis Spirulina cair peroral yang paling efektif dalam menurunkan kadar ureum dan kreatinin darah tikus putih ( $\mathrm{p}>0.05)$

Penurunan kadar ureum dan kreatinin darah tikus putih setelah pemberian Spirulina cair peroral, diakibatkan karena Spirulina mengandung Beta carotene, yang dapat mengikat $\mathrm{CCl}_{3}$. Pengikatan $\mathrm{CCl}_{3}$ oleh Beta carotene menyebabkan reaksi peroksidasi lipid tidak dapat berlangsung, sehingga memberikan waktu kepada sel ginjal untuk memperbaiki diri(11).

Beta carotene merupakan salah satu senyawa karotenoid, yang merupakan kelompok pigmen dan antioksidan alami yang mempunyai fungsi dalam menunda, memperlambat dan mencegah proses oksidasi lipid yang disebabkan oleh radikal bebas, dengan cara menunda atau mencegah terjadinya reaksi autooksidasi radikal bebas dalam oksidasi lipid(11).

\section{KESIMPULAN}

Berdasarkan hasil penelitian yang dilakukan dapat disimpulkan bahwa Spirulina cair yang diberikan secara peroral selama 3 minggu dapat memperbaiki kerusakan ginjal akibat pemberian $\mathrm{CCl}_{4}$ dilihat dari nilai ureum dan kreatinin darah. Tetapi dosis Spirulina cair peroral yang paling efektif dalam menurunkan kadar ureum dan kreatinin darah setelah pemberian $\mathrm{CCl}_{4}$ belum dapat ditentukan melalui penelitian ini.

\section{DAFTAR PUSTAKA}

1. Wijaya A. Radikal bebas dan parameter status antioksidan. Bandung: Lab Klinik Prodia; 1996. 1-6 p.

2. Tang D, Hu S, Dai F, Yi R, Gordin ML, Chen S, et al. Self-Templated Synthesis of Mesoporous Carbon from Carbon Tetrachloride Precursor for Supercapacitor Electrodes. ACS Applied Materials and Interfaces. 2016;8(11):6779-83.

3. Suzek H, Celik I, Dogan A, Yildirim S. Protective effect and antioxidant role of sweetgum (Liquidambar orientalis) oil against carbon tetrachloride-induced hepatotoxicity and oxidative stress in rats. Pharmaceutical Biology. 2016;54(3):451-7.

4. Scholten D, Trebicka J, Liedtke C, Weiskirchen R. The carbon tetrachloride model in mice. Laboratory Animals. 2015;49:4-11.

5. Yilmaz-Ozden T, Can A, Karatug A, Pala-Kara Z, Okyar A, Bolkent S. Carbon tetrachloride-induced kidney damage and protective effect of Amaranthus lividus L. in rats. Toxicology and Industrial Health. 2014;32(6):1143-52. 
6. Rajendran N, SR SK, K TM, P J. Biochemical evaluation of creatinine and urea in patients with renal failure undergoing hemodialysis. Journal of Clinical Pathology and Laboratory Medicine. 2017;1(2):1-5.

7. Henrikson R, Yoro C, Ruppert R. Fifth Printing, Revised Edition Online. 1989.

8. La RDE, Ciencias FDE. Sp/Rulina (Arthrospira) an Edible Microorganism a Review. Universitas Scientiarum. 2003;8(1):7-24.

9. Kirschweng B, Tátraaljai D, Földes E, Pukánszky B. Natural antioxidants as stabilizers for polymers. Polymer Degradation and Stability. 2017;145:25-40.

10. Chowdhury MRH, Sagor MAT, Tabassum N, Potol MA, Hossain H, Alam MA. Supplementation of Citrus maxima Peel Powder Prevented Oxidative Stress, Fibrosis, and Hepatic Damage in Carbon Tetrachloride $(\mathrm{CCl}<\mathrm{inf}>4</$ inf $>$ ) Treated Rats. Evidence-based Complementary and Alternative Medicine. $2015 ; 2015$.

11. Pisoschi AM, Pop A. The role of antioxidants in the chemistry of oxidative stress: A review. European Journal of Medicinal Chemistry. 2015;97:55-74. 